University of Nebraska - Lincoln

DigitalCommons@University of Nebraska - Lincoln

\title{
Persistence of rye (Secale cereale L.) chromosome arm 1RS in wheat (Triticum aestivum L.) breeding programs of the Great Plains of North America
}

\author{
Robert Graybosch \\ University of Nebraska - Lincoln, rgraybosch@gmail.com \\ Guihua Bai \\ Kansas State University \\ Paul ST. Amand \\ Kansas State University \\ Gautam Sarath \\ University of Nebraska-Lincoln, Gautam.sarath@ars.usda.gov
}

Follow this and additional works at: https://digitalcommons.unl.edu/usdaarsfacpub

Graybosch, Robert; Bai, Guihua; Amand, Paul ST.; and Sarath, Gautam, "Persistence of rye (Secale cereale L.) chromosome arm 1RS in wheat (Triticum aestivum L.) breeding programs of the Great Plains of North America" (2019). Publications from USDA-ARS / UNL Faculty. 2153.

https://digitalcommons.unl.edu/usdaarsfacpub/2153

This Article is brought to you for free and open access by the U.S. Department of Agriculture: Agricultural Research Service, Lincoln, Nebraska at DigitalCommons@University of Nebraska - Lincoln. It has been accepted for inclusion in Publications from USDA-ARS / UNL Faculty by an authorized administrator of DigitalCommons@University of Nebraska - Lincoln. 


\title{
Persistence of rye (Secale cereale L.) chromosome arm 1RS in wheat (Triticum aestivum L.) breeding programs of the Great Plains of North America
}

\author{
Robert Graybosch • Guihua Bai • Paul St. Amand • Gautam Sarath
}

Received: 25 October 2018/Accepted: 28 January 2019/Published online: 8 March 2019

(C) Springer Nature B.V. 2019

\begin{abstract}
Rye (Secale cereale L.) chromosome arm 1RS has been used world-wide by wheat (Triticum aestivum L.) breeding programs as a source of pestand pathogen-resistance genes, and to improve grain yield and stress tolerance. The most common vehicles used to access $1 \mathrm{RS}$ are various $1 \mathrm{AL} .1 \mathrm{RS}$ and 1BL.1RS wheat-rye chromosomal translocations. Over the past 25 years, advanced North American wheat breeding lines were evaluated, first by assay of secalin storage proteins, and later by use of DNA marker TSM0120, for the presence of these two translocations. Both methods provide accurate and efficient means of identifying and differentiating 1BL.1RS and 1A.1RS. Both 1Al.1RS and 1BL.1RS wheats were found in all tested years. 1AL.1RS lines were more common in southern Great Plains breeding programs. 1AL.1RS lines were released as cultivars at a frequency identical
\end{abstract}

Robert A. Graybosch: Retired.

Electronic supplementary material The online version of this article (https://doi.org/10.1007/s10722-019-00742-4) contains supplementary material, which is available to authorized users.

R. Graybosch $(\square) \cdot$ G. Sarath

USDA-ARS, WSFRU, 251 Filley Hall, University of

Nebraska, East Campus, Lincoln, NE 68583, USA

e-mail: rgraybosch@gmail.com

G. Bai · P. St. Amand

USDA-ARS, CGAHR, 3006 Throckmorton Hall, Kansas

State University, Manhattan, KS, USA to that of wild-type breeding lines. In contrast, 1BL.1RS breeding lines were developed by breeding programs throughout the Great Plains, but fewer were released as cultivars. Both 1RS translocation types persist in Great Plains breeding programs. The lower rate of release of 1BL.1RS cultivars no doubt is a consequence of the more drastic effects on breadmaking quality relative to those observed with 1AL.1RS.

Keywords Wheat $\cdot$ Rye $\cdot$ Chromosomal translocations - North American breeding programs . DNA protein markers

\section{Introduction}

Common wheat (Triticum aestivum L.), a product of interspecific hybridization and chromosome doubling (Kihara 1975; Matsuoka 2011) tolerates the loss or addition of its own chromosomes and those of other members of the Triticeae. In attempts to access potentially useful traits from many closely related species, wheat geneticists introduced alien chromosomes and chromosome fragments into wheat via interspecific hybridization (McFadden and Sears 1947). Some of the earliest successful interspecific hybrids were between wheat and rye (Secale cereale L.) (Leighty and Sando 1928; Florell 1931). Modern wheat production has heavily utilized genes from rye, particularly those found on chromosome arm 1RS. 
Useful traits found on that arm include resistance to various fungal and viral pathogens and insect pests, more efficient mineral absorption, enhanced stress tolerance, and fertility restoration in hybrid wheat production (Lukaszewski 2015). Rye chromosome arm 1RS is most commonly found in wheat cultivars in the form of 1BL.1RS wheat-rye chromosomal translocations. World-wide, hundreds of 1BL.1RS wheat cultivars have been bred and released (Lukaszewski 2015). In the Great Plains of North America, but less so in other parts of the world, 1AL.1RS cultivars, typically derived from the wheat germplasm line Amigo (Sebesta et al. 1995), are also common.

In 1BL.1RS and 1AL.1RS chromosomal translocations, the short arm of 1R replaces the short arms of either $1 \mathrm{~B}$ or $1 \mathrm{~A}$ of wheat. Given that replacement, wheat genes encoding low-molecular-weight glutenin (LMW) and gliadin grain-storage proteins are lost, and rye genes encoding secalin storage proteins are introduced to wheat. In wheats lacking 1RS, LMW glutenin subunits polymerize and add to the glutenin matrix responsible for dough strength. Due to either the loss of LMW glutenins and gliadins, the presence of the more hydrophilic secalins (Hussain and Lukow 1994), or both, processing-quality defects long have been associated with $1 \mathrm{RS}$ in wheat backgrounds (Zeller and Hsam 1983; Graybosch 2001). The effect, however, is not as pronounced in 1AL.1RS wheats as in those lines carrying 1BL.1RS (Graybosch et al. 1993).

The first 1RS cultivars released in the Great Plains of North America were the 1BL.1RS cultivar 'Siouxland', released in 1985 by the University of Nebraska (Schmidt et al. 1985) and the 1AL.1RS cultivar 'TAM-107' (Porter et al. 1987), released from Texas A\&M University. 'Siouxland' carries the 1BL.1RS translocation derived from the Russian wheat cultivar 'Kavkaz', and 'TAM-107' carries 1AL.1RS derived from wheat germplasm line Amigo (Graybosch 2001). Although both 'Siouxland' and 'TAM-107' were widely grown (Baenziger et al. 1989; Raeburn 1996), and heavily used as parents in North American breeding programs (Graybosch 2001), the release of 'Siouxland' was met with dismay by the wheat milling and baking industries, due to its poor dough strength and baking properties (Martin and Stewart 1990; Graybosch 2001). In the early 1990s, USDA Agricultural Research Service (ARS) scientists at Lincoln, Nebraska began screening advanced US breeding lines for the presence of 1AL.1RS and 1BL.1RS. This was done to assist breeders in making both release decisions and in selecting parental materials for new matings.

Breeding lines screened by the USDA-ARS primarily were derived from the USDA-coordinated regional nursery trials. Since 1931, the Uniform Regional Nursery Program has tested advanced breeding lines from public and private breeding programs in the US, with entries occasionally also supplied from Canada. Two such nurseries, the Southern (SRPN) and Northern (NRPN) Regional Performance Nurseries (USDA 2018), operate in the Great Plains region of North America. In the SRPN and NRPN, advanced breeding lines are tested in replicated field trials from Texas north to Alberta, Canada, and from the Missouri River west to the Rocky Mountains. The SRPN is tested from southern Texas to South Dakota, with most entries being derived from breeding programs based in Nebraska south to Texas. The NRPN is tested from Kansas north to Alberta, with entries typically from breeding programs based in Nebraska, the Dakotas, and Montana. Lines also are tested for disease and pest resistance, bread-making quality, presence of key molecular markers, and other traits. Lines entered in the SRPN and NRPN typically have already been tested for multiple years in their states of origin, with the regional nursery trials representing one of the last stages before cultivar-release decisions are made. Thus, entries represent the most elite lines from the submitting breeding programs at any given time.

From 1993 to 2010, 1RS was identified in SRPN and NRPN entries via the presence of rye secalin proteins in grain samples, by using sodium dodecyl sulfate polyacrylamide gel electrophoresis (SDSPAGE) separation of grain proteins (Graybosch et al. 1999). Commencing in 2010, USDA-ARS scientists at the USDA Central Small Grain Genotyping Lab (CSGGL) in Manhattan, KS (https://hwwgenotyping. ksu.edu) started screening the SRPN and NRPN entries with DNA markers for key traits and genes. In 2010 and 2011, both SDS-PAGE and DNA markers were applied in the 1 RS screen. As these initial results showed $100 \%$ agreement, the SDS-PAGE work was suspended. Recently, however, we decided to re-visit this topic and screen the 2012-2018 SRPN and NRPN again with SDS-PAGE. This was undertaken to determine the accuracy of the DNA-based markers, 
and to verify that $1 \mathrm{RS}$ was inherited as one large linkage block. Typically, recombination does not occur between 1RS and any wheat chromosome arms, unless present in a $P h$-background (Lukaszewski 2000). Disagreement of SDS-PAGE and DNA-based results could indicate the generation of a rare recombinant that separated secalin-encoding sequences from other genes on 1RS. As 1RS data now are available on the most advanced wheat breeding lines from Great Plains' programs, a secondary objective was to summarize the past 25 years of results, documenting the impact of 1RS on Great Plains wheat breeding and production.

\section{Materials and methods}

\section{SDS-PAGE}

Seed from all SRPN and NRPN 2012-2018 entries was obtained from remnant samples of the original entries maintained in cold storage at the Stewart Seed Lab, University of Nebraska, Lincoln. Eight seeds of each entry were placed in $5 \mathrm{ml}$ screw-top vials along with three $6.35 \mathrm{~mm}$ stainless-steel bearing balls per sample and ground to meal with a Geno/Grinder ${ }^{\circledR}$ (SPEX SamplePrep Metuchen, NJ, USA). Samples were ground at $1500 \mathrm{rpm}$ for three min to obtain homogeneous meal. A $25 \mathrm{mg}$ aliquot was weighed into a $1.5 \mathrm{ml}$ conical Eppendorf tube, $1 \mathrm{ml} \mathrm{H}_{2} \mathrm{O}$ added, and samples placed on a laboratory shaker at $150 \mathrm{rpm}$ for 30-60 min. Following centrifugation at $14,000 \mathrm{rpm}$ for $5 \mathrm{~min}, 300 \mu \mathrm{l}$ supernatant was removed and added to a fresh tube containing $700 \mu \mathrm{l}$ $100 \%$ ethanol. The solution was stored at $-20{ }^{\circ} \mathrm{C}$ for $1 \mathrm{~h}$, recentrifuged, and $200 \mu \mathrm{l}$ supernatant dried in a Labconco Centrivap SpeedVac Concentrator (Kansas City, MO). Dried samples were re-suspended in $250 \mu \mathrm{l}$ of sample buffer (Graybosch and Morris 1990) and $5 \mu \mathrm{l}$ aliquots loaded and separated on 12\% Bio Rad Criterion TGX Stain-Free Protein Gels (Herucles, CA), by using a Tris-glycine buffer (Graybosch and Morris 1990). Proteins were visualized with silver-nitrate staining (Graybosch and Morris 1990). Each gel also contained control samples of the cultivars 'Siouxland' (1BL.1RS) and 'TAM-107' (1AL.1RS). Secalins were identified as per Graybosch et al. (1999).
Identification of secalins by mass-spectrometry

Mass spectrometry of peptides released from proteasedigested gel bands was used to confirm the identify of diagnostic proteins for 1BL.1RS and 1AL.1RS. For these experiments, proteins were extracted as described above, except that after the $-20{ }^{\circ} \mathrm{C}$ treatment and centrifugation, the entire $1 \mathrm{ml}$ supernatant was dried in the Labconco Centrivap SpeedVac Concentrator. The dried sample was again suspended in $250 \mu \mathrm{l}$ extraction buffer (above) and $15 \mu \mathrm{l}$ aliquots loaded on $12 \%$ gels as described above. Proteins were visualized after staining with Coomassie Brilliant Blue R-250 (300 mg in 45\% v/v methanol, $10 \%$ acetic acid, $45 \% \mathrm{H}_{2} \mathrm{O}$ ). After de-staining with $10 \%$ methanol/7\% acetic acid, diagnostic bands (see Results and Discussion) were cut from the gels and analyzed at the University of Nebraska Lincoln, Proteomics and Metabolomics Core Facility (https://biotech.unl.edu/ proteomics-and-metabolomics).

Excised gel bands were washed with ammonium bicarbonate/acetonitrile to remove the stain and SDS. Trypsin was added and digestion carried out overnight at $37{ }^{\circ} \mathrm{C}$, followed by chymotrypsin digestion at $30^{\circ} \mathrm{C}$ overnight. Peptides were extracted from the gel pieces, dried down, and re-dissolved in an aqueous solution of $2.5 \% \mathrm{v} / \mathrm{v}$ acetonitrile, $0.1 \%$ formic acid. Each digest was separated by nano-LC-MS/MS using a gradient on a $0.075 \mathrm{~mm} \times 250 \mathrm{~mm} \mathrm{C18}$ column feeding for $1 \mathrm{~h}$ into a Q-Exactive HF mass spectrometer (Thermo Fisher Scientific, Lenexa, KS, USA). All MS/MS samples were analyzed with Mascot (Matrix Science, London, UK; version 2.6.1). Mascot was searched with a fragment ion mass tolerance of $0.060 \mathrm{Da}$ and a parent ion tolerance of 10.0 PPM. De-amidated asparagine and glutamine and oxidized methionine were specified in Mascot as variable modifications. Scaffold (version Scaffold_4.8.4, Proteome Software Inc., Portland, OR) was used to validate MS/MS based peptide and protein identifications. Peptide identifications were accepted if they could be established at greater than $80.0 \%$ probability by the Peptide Prophet algorithm (Keller et al. 2002), with Scaffold delta-mass correction. Protein identifications were accepted if they could be established at greater than $99.0 \%$ probability and contained at least 2 identified peptides. Protein probabilities were assigned by the Protein Prophet algorithm (Nesvizhskii et al. 2003), Proteins that contained similar peptides and could not 
be differentiated based on MS/MS analysis alone were grouped to satisfy the principles of parsimony. Proteins sharing significant peptide evidence were grouped into clusters using Scaffold 4 analysis tool (Proteome Software, Portland, OR, USA: http://www. proteomesoftware.com/).

\section{Rye SSR marker TSM120}

Rye SSR marker SCM9 (Saal and Wricke 1999) has been used by USDA-ARS genotyping labs (https:// maswheat.ucdavis.edu/protocols/Drought/index.htm) for detection of 1BL.1RS, and 1AL.1RS translocations. However, SCM9 has sometimes produced both false positives and false negatives at the USDA-ARS CSGGL (data not shown). We discovered a marker that is more reliable for detecting wheat-rye translocations by screening 29 rye SSR markers previously mapped by Kofler et al. (2008) to the distal bin of rye chromosome 1. All 29 rye markers were tested on a panel of wheat lines known to have either wheat-rye translocations or no translocation (data not shown). The panel consisted of 44 wheat cultivars and breeding lines, 22 known to carry $1 \mathrm{AL} .1 \mathrm{RS}, 10$ with $1 \mathrm{BL} .1 \mathrm{RS}$, and 12 wild-type (non-translocation) lines. SSR marker TSM120 was found to clearly and repeatably distinguish between non-1RS, 1AL.1RS, and 1BL.1RS wheat-rye translocations. No PCR amplification occurred in any of the 12 wheat lines without 1RS translocations. PCR products from 1AL.1RS translocation lines are $358 \mathrm{bp}$ long, while 1BL.1RS translocation lines produce a 345 bp PCR product. Primer sequences for gel-based detection of TSM0120 fragments are: TSM0120F 5'-CCG CCG TCC TCC TCC T- $3^{\prime}$ and TSM0120R 5'-AGA CGG CAG GCA TGG AT- $3^{\prime}$. To use fluorescently labeled primers in a capillary sequencer, primer TSM0120F was replaced with an 18-bp tailed forward primer: TSM0120F18 5'ACG ACG TTG TAA AAC GAC CCG CCG TCC TCC TCC T-3'. As expected, the resulting fragment sizes increased by $18 \mathrm{bp}$.

DNA marker analysis

All 2010-2018 entries in the NRPN and SRPN were screened with TSM0120. Each $13 \mu$ PCR reaction contained 20-80 ng DNA extracted from 4 to 8 seedlings (except with single-seed samples as noted below), $50 \mathrm{nM}$ of M13-tailed forward primer, $100 \mathrm{nM}$ of reverse primer, $50 \mathrm{nM}$ fluorescence-labeled M13 primer, $200 \mathrm{uM}$ of each dNTP, $1.3 \mu \mathrm{l} 10 \mathrm{X}$ ammonium sulfate PCR buffer, $2.5 \mathrm{mM} \mathrm{MgCl} 2$, and 1 unit of Taq polymerase (various vendors). PCR was performed by following a $56{ }^{\circ} \mathrm{C}$ touch-down program (Liu et al. 2008) in a DNA Engine ${ }^{\circledR}$ Peltier Thermal Cycler (BioRad Lab, Hercules, CA, USA). Up to four different plates of PCR products labeled with one of four dyes (FAM, VIC, NED, and PET) were pooled into one plate by using a Biomek $\mathrm{NX}^{\mathrm{P}}$ liquid handling system (Beckman Coulter Inc., Brea, CA, USA). The pooled PCR products were analyzed with an ABI Prism 3730 DNA Sequencer (Applied Biosystems, Foster City, CA, USA), and their fragment lengths and amplicon polymorphisms were scored with GeneMarker (SoftGenetics LLC, State College, PA, USA).

Scoring and statistical analysis

Scoring of samples was double-blind. DNA marker analysis was performed and marker data interpreted, before SDS-PAGE evaluations were conducted. SDSPAGE analyses were conducted and data scored, without consulting DNA marker results. Samples that disagreed after the first evaluation were retested as single-seed or single-plant samples with both the SDSPAGE and DNA marker protocols as described above.

The frequency of 1BL.1RS and 1AL.1RS in the SRPN and NRPN was summarized in relation to the number of entries per year. Long-term control cultivars included in the nurseries were excluded from the frequency analysis. No attempt was made to distinguish homogeneous lines from heterogeneous. If $1 \mathrm{RS}$ was detected, the sample was scored as such. The number of breeding lines released as cultivars (as of 2018), also was determined for 1BL.1RS, 1AL.1RS, and wild-type (WT) lines. Chi square analysis was used to compare frequencies between the two nurseries, and between released and non-released breeding lines. Computations were performed in Excel.

\section{Results and discussion}

Identities of the diagnostic proteins used in SDSPAGE evaluations (Fig. 1a) were validated by analysis of peptides released from tryptic/chymotryptic digests of excised gel bands followed by mass spectrometry. All 1RS lines produce a protein band 
Fig. 1 Enrichment and identification of secalins in 1 RS wheats. a Secalins separated by SDS-PAGE. Bands corresponding to 41 , 40 and $39 \mathrm{kD}$ secalins and the unknown $70 \mathrm{kDa}$ protein are marked with arrows. b Identification of peptides arising from omega secalins. Peptides identified by mass spectrometry following proteolytic digests of isolated putative secalin bands (see panel a) are highlighted in gray

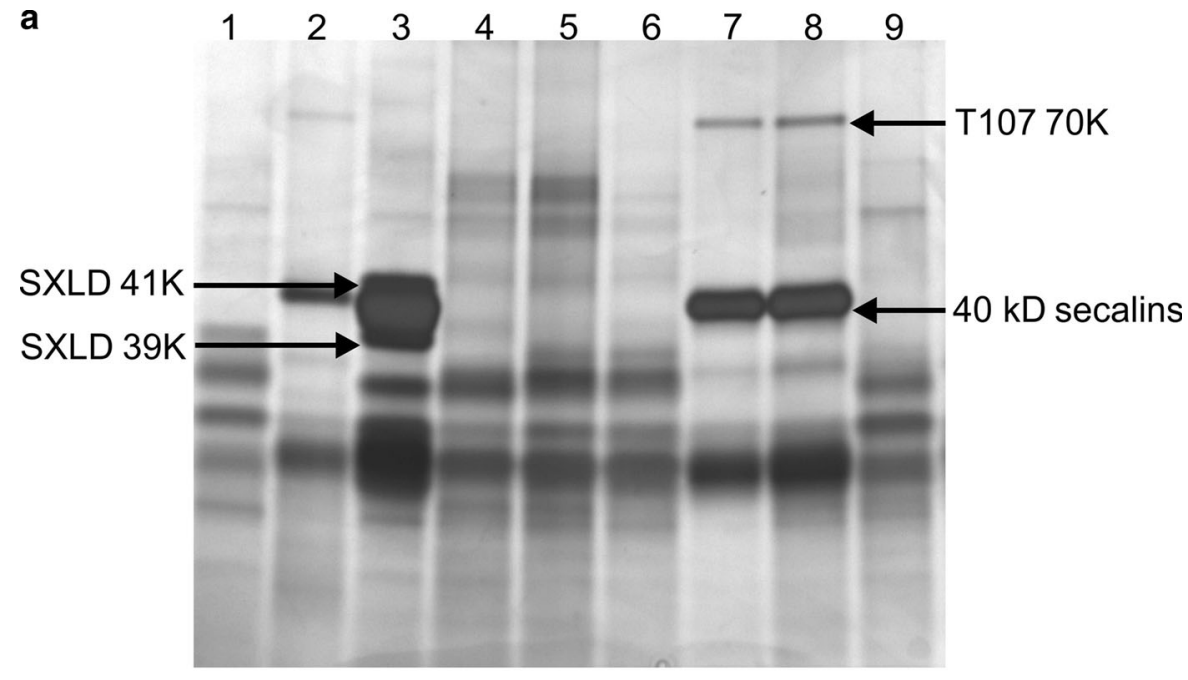

b

\author{
AAB58403.1 (100\%), 41,622.8 Da \\ omega secalin. (Secale cereale) \\ 4 exclusive unique peptides, 9 exclusive unique spectra, \\ 78 total spectra, $179 / 357$ amino acids (50\% coverage)
}

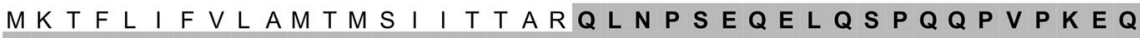

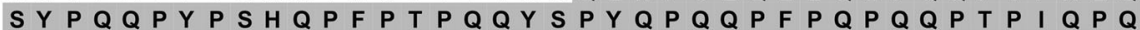

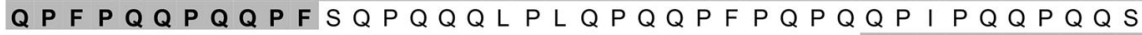
$F P Q Q P Q R P E Q Q F P Q Q P Q Q \mid I P Q Q T Q Q P F P L Q P Q Q P F P Q Q P$

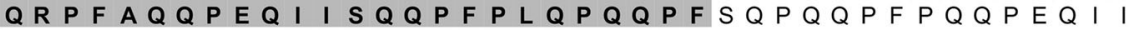
$P Q Q P Q Q P S P L Q P Q Q P F S Q Q P Q R P Q Q P F P Q Q P Q Q \mid I P Q Q P Q$

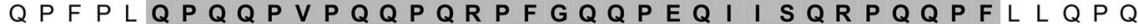
$Q P F S Q P Q Q P F L Q Q P G Q|| P Q Q P Q Q P F P L Q P Q Q P F P Q Q P E Q$ I I S E P Q Q P F L $P$ PQ $P S P Q Q P Q L P F P Q P Q Q P F \vee V \vee V$
\end{abstract}

recognized as secalins with an apparent molecular mass of $40 \mathrm{kD}$ (Fig. 1a; Graybosch et al. 1999). In 1BL.1RS lines, two additional bands, herein designated SXLD 41K and SXLD 39K, migrate above and below this large $40 \mathrm{kD}$ band (Fig. 1a). 1AL.1RS lines also produce a unique protein, designated $\mathrm{T} 107 \mathrm{70K}$. The $40 \mathrm{kD}$ cluster, SXLD 41K, and SXLD 39K all were positively identified as secalins by mass spectrometry (Fig. 1b). T107 70K, however, could not be identified. Peptide sequences of T107 70K were searched against the entire plant database in NCBIprot (https://www.ncbi.nlm.nih.gov/protein)—6,481,660 entries - and no matches to secalins (or gliadins) were detected. Protein T107 70K was always found in lines derived from known 1AL.1RS parents and in lines displaying the 1AL.1RS pattern from DNA marker TSM0120. Proteins SXLD 41K and SXLD 39K always co-existed in lines carrying 1BL.1RS as detected by TSM0120.
Exclusive of control cultivars, 525 breeding lines were entered in the 2012-2018 NRPN and SRPN. Results of the double-blind scoring of 1RS presence via SDS-PAGE and DNA marker TSM0120 initially agreed on all but nine entries, resulting in an error frequency of $1.7 \%$. DNA marker TSM0120 and SDSPAGE assays were re-conducted on 12 single seed samples of each of these nine lines, again were scored double-blind. In this second round of screening, five samples were scored non-1RS by both methods, two were scored 1BL.1RS by both methods, and two still disagreed. The two breeding lines in disagreement were scored non-1RS by TSM0120 and heterogeneous by SDS-PAGE. One sample had only one of 12 seeds with secalins, a frequency that could have resulted from mechanical mixing at harvest or human error. The second sample had six of 12 seeds with secalins on SDS-PAGE. DNA marker TSM0120, therefore, is a highly effective rapid screening tool, and the 
infrequent disagreements between marker and protein data were most likely due to sample heterogeneity, and not due to some rare recombination events. Storage protein and 1RS heterogeneity has been reported in Great Plains wheat breeding programs, where selection can commence at the $\mathrm{F}_{3}$ or $\mathrm{F}_{4}$ generation (Graybosch 1992; Moreno-Sevilla et al. 1995), whereas recombination between 1RS and corresponding wheat chromosomal arms occurs only in the presence of ph- mutants (Lukaszewski 2000).

Results from the 2012-2018 nurseries were combined with those from 1993 to 2011 to examine changes, if any, in frequencies of 1RS over time. All lines tested are listed in the Supplementary Materials and also at: https://www.ars.usda.gov/plains-area/ lincoln-ne/wheat-sorghum-and-forage-research/docs/ hard-winter-wheat-regional-nursery-program/ research/ (USDA 2018). 1AL.1RS wheats were observed at a statistically significant higher frequency (14.7\%, Table 1) in the southern Great Plains SRPN than in the northern NRPN (4.3\%). 1BL.1RS lines, in contrast, were observed at statistically indistinguishable frequencies (Table 1) in the two nurseries. Within each nursery, the frequency of the two 1RS types differed significantly (Table 1) with 1BL.1RS lines being far more common than 1AL.1RS in the NRPN. The difference in the SRPN (Table 1) was slight, but there were significantly more 1AL.1RS lines than 1BL.1RS lines.

Visualization of the frequencies and total numbers of 1AL.1RS and 1BL.1RS in the SRPN and NRPN over time (Figs. 2, 3, 4, 5) shows a relatively constant supply of $1 \mathrm{RS}$ entries, with some waxing and waning. In the SRPN, 1AL.1RS wheats represented more than $20 \%$ of the entries in the early 1990s. This frequency has declined slightly over time, never exceeding $5 \%$ in

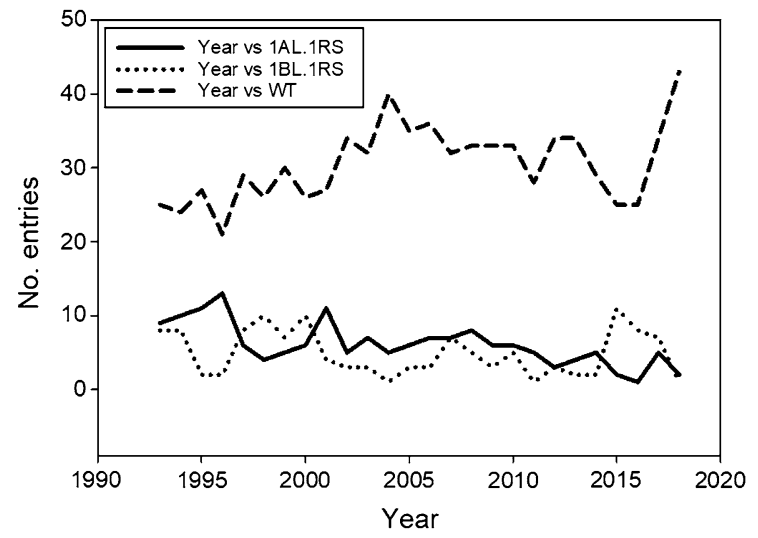

Fig. 2 Total number of 1AL.1RS, 1BL.1RS and wild-type (WT) entries, exclusive of controls, Southern Regional Performance Nursery

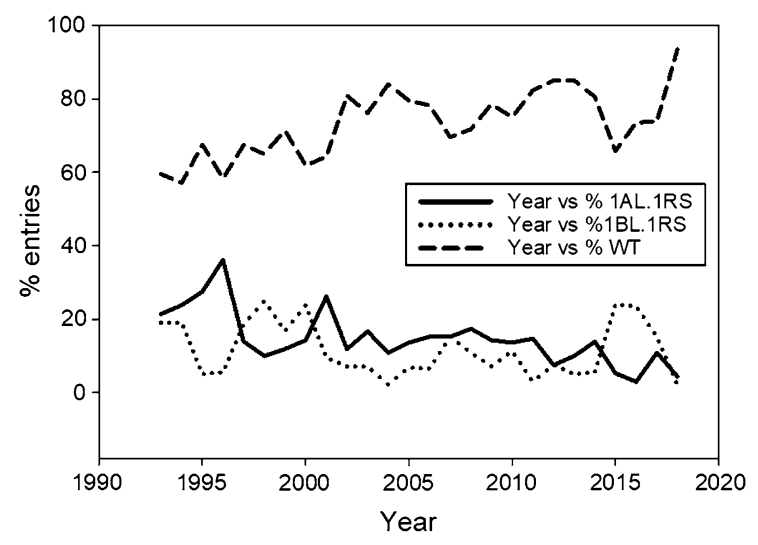

Fig. 3 Percentage 1AL.1RS, 1BL.1RS and wild-type (WT) entries, exclusive of controls, Southern Regional Performance Nursery

the most recent 5 years tested. In the NRPN, 1AL.1RS entries rarely exceeded $5 \%$ in any of the 25 years evaluated. The frequency of 1BL.1RS in both

Table 1 Frequency of 1RS wheat-rye translocation lines in USDA-ARS coordinated hard winter wheat breeding trials, 1993-2018

\begin{tabular}{|c|c|c|c|c|c|c|c|c|c|}
\hline \multirow[t]{2}{*}{ Nursery } & \multirow[t]{2}{*}{ Entries tested $^{\mathrm{a}}$} & \multicolumn{2}{|c|}{ 1AL.1RS } & \multicolumn{2}{|c|}{ 1BL.1RS } & \multicolumn{2}{|c|}{ Wild-type } & \multirow{2}{*}{$\begin{array}{l}\chi^{2}(1 \mathrm{AL} .1 \mathrm{RS} \mathrm{vs} \\
\text { 1BL.1RS })\end{array}$} & \multirow[t]{2}{*}{$p$} \\
\hline & & No. & $\%$ & No. & $\%$ & No. & $\%$ & & \\
\hline NRPN & 761 & 33 & 4.3 & 77 & 10.1 & 651 & 88.6 & 59.4 & $<0.001$ \\
\hline SRPN & 1081 & 159 & 14.7 & 127 & 11.8 & 795 & 73.55 & 6.4 & $<0.025$ \\
\hline$\chi^{2}$ (NRPN vs SPRN) & & 55.7 & & 1.82 & & & & & \\
\hline$p$ & & $<0.001$ & & $>0.10$ & & & & & \\
\hline
\end{tabular}

NRPN Northern Regional Performance Nursery, SRPN Southern Regional Performance Nursery

${ }^{a}$ Includes all experimental lines entered; long-term control cultivars removed 


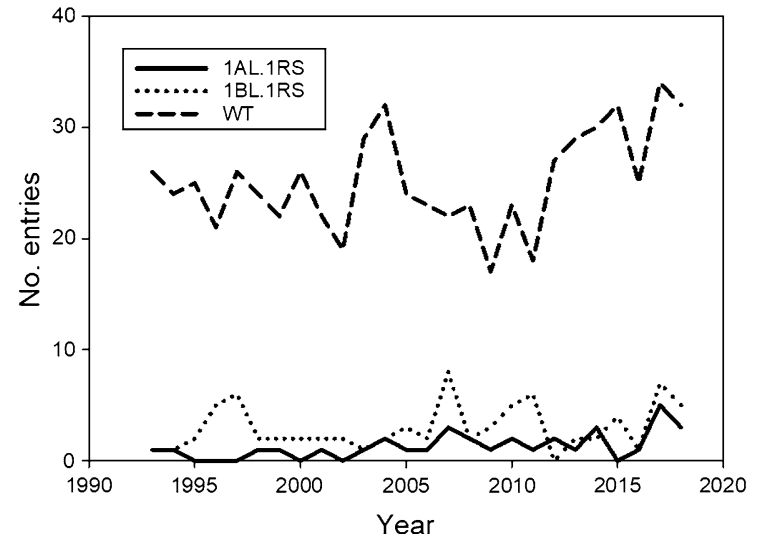

Fig. 4 Total number of 1AL.1RS, 1BL.1RS and wild-type (WT) entries, exclusive of controls, Northern Regional Performance Nursery

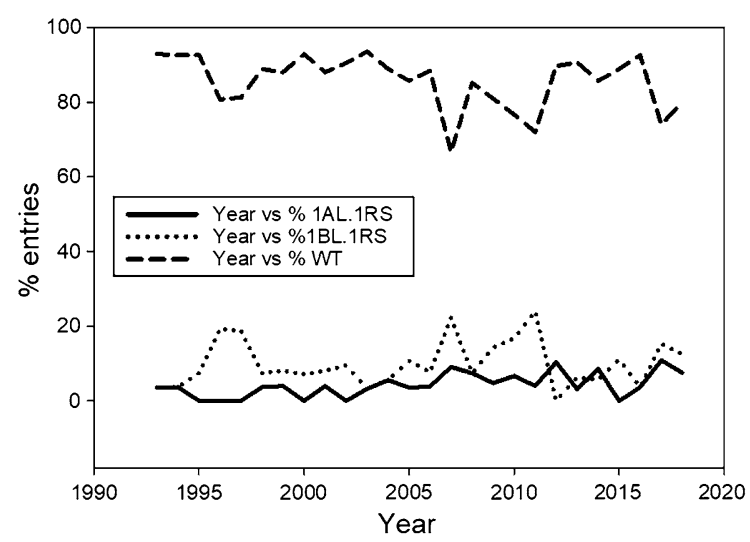

Fig. 5 Percentage 1AL.1RS, 1BL.1RS and wild-type (WT) entries, exclusive of controls, Northern Regional Performance Nursery

nurseries fluctuated. In the SRPN in the late 1990s, 1BL.1RS approached a frequency of $20 \%$ for several years, then declined, only to increase markedly around 2015 (Figs. 2, 3). Likewise, 1BL.1RS entries approached or exceeded $15 \%$ in the NRPN in the mid-1990s, again in 2006 and 2011 (Figs. 4, 5), and declining during intervals between these years.

Nearly all cultivars released in the Great Plains region are evaluated in either or both the SRPN or NRPN. Of 1040 unique, wild-type breeding lines evaluated in these trials from 1993 to 2018, 180 (as of this writing) have been released as cultivars (Table 2; USDA 2018). The frequency (18.1\%) of 1AL.1RS lines released as cultivars, to date, is not significantly different than the frequency (17.3\%) of wild-type lines released (Table 2). The frequency (11.4\%) of
1BL.1RS breeding lines ultimately released as cultivars, however, is significantly lower than that of wildtype cultivars (Table 2). Great Plains winter wheat 1RS cultivars released from 1993 to 2018 are listed in Table 3.

Observations may be summarized as follows: Both 1Al.1RS and 1BL.1RS wheats have been observed at a relatively constant frequency over the past 25 years in Great Plains breeding programs. 1AL.1RS lines are more common in southern Great Plains breeding programs, which typically enter lines in the SRPN. 1AL.1RS lines are released as cultivars at a frequency identical to that of wild-type breeding lines. In contrast, 1BL.1RS breeding lines are produced by breeding programs across the Great Plains, but fewer are released as cultivars. Both 1RS translocation types persist in Great Plains breeding programs. The lower rate of release of 1BL.1RS cultivars no doubt is a consequence of the more drastic effects on breadmaking quality relative to those observed with $1 \mathrm{AL} .1 \mathrm{RS}$ (Graybosch et al. 1993). Among Great Plains wheat breeders, the perception is that 1AL.1RS has little, if any, negative quality effects. At a recent field day, one such breeder was heard to utter "we don't fear this translocation" with reference to 1AL.1RS quality.

Recent literature suggests the situation for 1BL.1RS lines is similar in many other parts of the world. 1BL.1RS was observed at frequencies greater than $25 \%$ in samples of both elite cultivars and advanced breeding lines from Pakistan tested in 2010 (Tahir et al. 2014). In Bulgaria, 1BL.1RS was observed in $10 \%$ of cultivars tested (Landjeva et al. 2006). Thirteen percent of Hungarian wheats tested in 2005 carried 1BL.1RS, although 50\% of the cultivars registered in 1994 carried this translocation (Purnhauser et al. 2011). A compendium of released lines with 1RS maintained by Schlegel (2016) lists many hundreds of cultivars world-wide. 1AL.1RS cultivars originally were restricted to the US; however, Lukaszewski (2015) noted that their frequency and distribution outside of the US has increased since the year 2000 .

Lukaszewski (2015) further observed "It is interesting that most of the spread of the translocation occurred when, or after, the rye resistance genes have broken down and contributed little value in breeding." If most of the resistance genes on 1RS are, in fact, broken, how can one explain its continued presence? Observations suggest that $1 \mathrm{RS}$ contributes other 
Table 2 Frequency of cultivar release from breeding lines entered in USDA-ARS coordinated hard winter wheat breeding trials, $1993-2018$

\begin{tabular}{lcclll}
\hline Genotype & $\mathrm{N}^{\mathrm{a}}$ & $\mathrm{N}$ released as cultivars & \% released & $\chi^{2}$ (vs wild-type) & $p$ \\
\hline 1AL.1RS & 138 & 25 & 18.1 & 0.04 & 3.24 \\
1BL.1RS & 141 & 16 & 11.4 & 17.3 & \\
Wild-type & 1040 & 180 & & & \\
\hline
\end{tabular}

${ }^{\mathrm{a}} \mathrm{N}=$ number of unique genotypes. Redundant entries between SRPN and NRPN omitted

Table 3 Great Plains 1 RS cultivars released 1993-2018

\begin{tabular}{|c|c|c|c|c|c|}
\hline Genotype & Cultivar & Year released & Genotype & Cultivar & Year released \\
\hline 1AL.1RS & Hickok & 1993 & 1BL.1RS & Custer & 1994 \\
\hline 1AL.1RS & Ogallala & 1993 & 1BL.1RS & Tonkawa & 1994 \\
\hline 1AL.1RS & Nekota & 1994 & 1BL.1RS & Quantum 7406 & 1997 \\
\hline 1AL.1RS & Niobrara & 1994 & 1BL.1RS & Quantum 7424 & 1997 \\
\hline 1AL.1RS & Quantum 579 & 1994 & 1BL.1RS & Cougar & 2000 \\
\hline 1AL.1RS & TAM 110 & 1997 & 1BL.1RS & Wendy & 2004 \\
\hline 1AL.1RS & Hondo & 1998 & 1BL.1RS & Endurance & 2004 \\
\hline 1AL.1RS & Nuhorizon & 2000 & 1BL.1RS & Keota & 2005 \\
\hline 1AL.1RS & Above & 2001 & 1BL.1RS & Shocker & 2005 \\
\hline 1AL.1RS & AP502 CL & 2001 & 1BL.1RS & Art & 2006 \\
\hline 1AL.1RS & Charter & 2004 & 1BL.1RS & Hitch & 2008 \\
\hline 1AL.1RS & Fannin & 2004 & 1BL.1RS & Robidoux & 2010 \\
\hline 1AL.1RS & TAM 112 & 2005 & 1BL.1RS & SY Wolf & 2010 \\
\hline 1AL.1RS & TAM 303 & 2005 & 1BL.1RS & Gallagher & 2012 \\
\hline 1AL.1RS & Aspen & 2006 & 1BL.1RS & Ruth & 2015 \\
\hline 1AL.1RS & Darrell & 2006 & 1BL.1RS & Larry & 2016 \\
\hline 1AL.1RS & $\mathrm{T} 140$ & 2007 & & & \\
\hline 1AL.1RS & Armour & 2008 & & & \\
\hline 1AL.1RS & $\mathrm{T} 151$ & 2008 & & & \\
\hline 1AL.1RS & $\mathrm{T} 153$ & 2008 & & & \\
\hline 1AL.1RS & $\mathrm{T} 154$ & 2008 & & & \\
\hline 1AL.1RS & $\mathrm{T} 158$ & 2009 & & & \\
\hline 1AL.1RS & Judee & 2011 & & & \\
\hline 1AL.1RS & TAM 305 & 2012 & & & \\
\hline 1AL.1RS & AG Robust & 2014 & & & \\
\hline
\end{tabular}

beneficial effects to recipient wheats, including greater biomass (Shearman et al. 2005; Foulkes et al. 2007), increased heterosis in hybrid wheats (Owuoche et al. 2003), and increased root size (Waines and Ehdae 2007). Thus, 1 RS may convey to newly developed breeding lines enough of a yield advantage, in at least some backgrounds and environments, that breeders are unconsciously selecting and maintaining it. 1RS also might be maintained in breeding programs because it is common in those elite lines that may be selected as parents. Inspection of pedigrees of lines entered in the SRPN and NRPN (USDA 2018) indicates most are derived from matings of experimental breeding lines, before any such lines are released as cultivars. Breeders select the best lines from their own and their colleagues' advanced trials, and enter them into their crossing blocks, without waiting to see if said lines are to be released or not. The 
idea is to pyramid useful genes, and, in doing so, 1RS likely is present, perpetuating it even if the lines carrying it fail to achieve cultivar status.

Lukaszewski (2015) described 1BL.1RS as the "poster child" of alien introgressions. In the Great Plains of North America, it is joined and even exceeded by 1AL.1RS. The success of both translocations in North American winter wheat cultivar development, as described herein, and in both winter and spring wheats world-wide (Crespo-Herrera et al. 2017) highlight the value of alien introgressions, as proposed by McFadden and Sears (1947) many decades ago.

Acknowledgements The authors thank the many Great Plains wheat breeders who have entered lines in the SRPN and NRPN over the years, Lori Divis, Steve Masterson, and Nathan Palmer for technical assistance, and Michael Naldrett and Sophie Alvarez Y. Albala of the University of Nebraska Center for Biotechnology for proteomic analyses.

\section{Compliance with ethical standards}

Conflict of interest The authors declare no conflict of interest.

\section{References}

Baenziger PS, Peterson CJ, Mattern PJ (1989) 1989 Nebraska Cooperative Wheat Investigations. https://agronomy.unl. edu/Baenziger/annualreports/WheatRep89.pdf

Crespo-Herrera LA, Garkava-Gustavsson L, Åhman I (2017) A systematic review of rye (Secale cereale L.) as a source of resistance to pathogens and pests in wheat (Triticum aestivum L.). Hereditas 154:14. https://doi.org/10.1186/ s41065-017-0033-5

Florell VH (1931) A cytological study of wheat X rye hybrids and back crosses. J Agric Res 42:341-362

Foulkes MJ, Snape JW, Shearman VJ, Reynolds MP, Gaju O, Sylvester-Bradley R (2007) Genetic progress in yield potential in wheat: recent advances and future prospects. J Agric Sci 145:17-29

Graybosch RA (1992) The high-molecular-weight glutenin composition of cultivars, germplasm and parents of U.S. red winter wheats. Crop Sci 32:1151-1155

Graybosch RA (2001) Uneasy unions: quality effects of rye chromatin transfers to wheat. J Cereal Sci 33:3-16

Graybosch RA, Morris R (1990) An improved SDS-PAGE method for the analysis of wheat endosperm storage proteins. J Cereal Sci 190:201-212

Graybosch RA, Peterson CJ, Hansen LE, Worrall D, Shelton D, Lukaszewski A (1993) Comparative flour quality and protein characteristics of $1 \mathrm{BL} / 1 \mathrm{RS}$ and $1 \mathrm{AL} / 1 \mathrm{RS}$ wheatrye translocation lines. J Cereal Sci 17:95-106
Graybosch RA, Lee J-H, Peterson CJ, Porter DR, Chung OK (1999) Genetic, agronomic and quality comparisons of two 1AL.1RS wheat-rye chromosomal translocations. Plant Breeding 118:125-130

Hussain A, Lukow OM (1994) Characterization of 1B/1R translocation in wheat using water extractable protein concentrate. Euphytica 78:109-113

Keller A, Nesvizhskii AI, Kolker E, Aebersold R (2002) Empirical statistical model to estimate the accuracy of peptide identifications made by MS/MS and database search. Anal Chem 74:5383-5392

Kihara H (1975) Origin of cultivated plants with special reference to wheat. Seiken Ziho 25:1-26

Kofler R, Bartos J, Gong L, Stift G, Suchankova P, Simkova H, Berenyi M, Burg K, Dolezel J, Lelley T (2008) Development of microsatellite markers specific for the short arm of rye (Secale cereale L.) Chromosome 1. Theor Appl Genet 117:915-926. https://doi.org/10.1007/s00122-008-0831-2

Landjeva S, Korzum V, Ganeva G (2006) Evaluation of genetic diversity among Bulgarian winter wheat (Triticum aestivum L.) varieties during the period 1925-2003 using microsatellites. Genet Resour Crop Evol 53:1605-1614

Leighty CE, Sando WJ (1928) Natural and artificial hybrids of a Chinese wheat and rye. J Hered 19:23-27

Liu S, Cai S, Graybosch RA, Chen C, Bai G (2008) Quantitative trait loci for resistance to pre-harvest sprouting in U.S. hard white winter wheat Rio Blanco. Theor Appl Genet 117:691-699

Lukaszewski AJ (2000) Manipulation of the 1RS.1BL translocation in wheat by induced homoeologous recombination. Crop Sci 40:216-225

Lukaszewski AJ (2015) Introgressions between wheat and rye. In: Molnár-Láng M, Ceoloni C, Dolezel J (eds) Alien introgression in wheat. Springer, Basel, pp 163-189

Martin DJ, Stewart BG (1990) Dough stickiness in rye-derived wheat cultivars. Euphytica 51:77-86

Matsuoka Y (2011) Evolution of polyploid triticum wheats under cultivation: the role of domestication, natural hybridization and allopolyploid speciation in their diversification. Plant Cell Physiol 52:750-764

McFadden ER, Sears ER (1947) The genome approach in radical wheat breeding. J Am Soc Agron 39:1011-1026

Moreno-Sevilla B, Baenziger PS, Shelton DR, Peterson CJ, Graybosch RA (1995) Agronomic performance and enduse quality of $1 \mathrm{~B}$ vs $1 \mathrm{BL} .1 \mathrm{RS}$ genotypes derived from winter wheat 'Rawhide'. Crop Sci 35:1607-1612

Nesvizhskii AI, Keller A, Kolker E, Aebersold R (2003) A statistical model for identifying proteins by tandem mass spectrometry. Anal Chem 75:4646-4658

Owuoche JO, Sears RG, Brown-Guedira GL, Gill BS, Fritz AK (2003) Heterotic effects of wheat-rye chromosomal translocations on agronomic traits of hybrid wheat (Triticum aestivum L.) under an adequate moisture regime. Euphytica 132:67-77

Porter K, Worrall W, Gardenhire J, Gilmore E, McDaniel M, Tuleen N (1987) Registration of 'TAM 107'wheat. Crop Sci 27:818-819

Purnhauser L, Bona L, Lang L (2011) Occurrence of 1BL.1RS wheat-rye chromosome translocation and the Sr36/Pm6 resistance gene cluster in wheat cultivars registered in Hungary. Euphytica 179:287-295 
Raeburn P (1996) The last harvest: the genetic gamble that threatens to destroy American agriculture. Bison Books, University of Nebraska Press, Lincoln

Saal B, Wricke G (1999) Development of simple sequence repeat markers in rye (Secale cereale L.). Genome 42:964-972

Schlegel R (2016) Current list of wheats with rye and alien introgression. http://www.rye-gene-map.de/rye-introgress ion/index.html

Schmidt JW, Johnson VA, Mattern PJ, Dreier AF, McVey DV, Hatchett JH (1985) Registration of 'Siouxland' wheat. Crop Sci 25:1130-1131

Sebesta EE, Wood EA, Porter DR, Webster JA, Smith EL (1995) Registration of Amigo wheat germplasm resistant to greenbug. Crop Sci 35:293

Shearman VJ, Sylvester-Bradley R, Scott RK, Foulkes MJ (2005) Physiological processes associated with wheat yield progress in the UK. Crop Sci 45:175-185

Tahir R, Bux H, Kazi AG, Rasheed A, Napar AA, Ajmal SU, Mujeeb-Kazi A (2014) Evaluation of Pakistani wheat germplasm for T1BL.1RS chromosome translocation. J Agric Sci Technol 16:421-432

USDA (2018) Hard winter wheat regional nursery program. https://www.ars.usda.gov/plains-area/lincoln-ne/wheat-so rghum-and-forage-research/docs/hard-winter-wheat-regio nal-nursery-program/research/

Waines JG, Ehdae B (2007) Domestication and crop physiology: roots of green-revolution wheat. Ann Bot 100:991-998

Zeller FJ, Hsam SLK (1983) Broadening the genetic variability of cultivated wheat by utilizing rye chromatin. In: Sakamoto S (ed) Proceedings of the sixth international wheat genetics symposium, Japan, Kyoto, pp 161-173

Publisher's Note Springer Nature remains neutral with regard to jurisdictional claims in published maps and institutional affiliations. 